Dampak Covid-19 Terhadap Perubahan Harga Saham dan Volume Transaksi

(Studi Kasus Pada PT. Ramayana Lestari Sentosa, Tbk.)

\author{
Ifa Nurmasari ${ }^{1}$
}

${ }^{1)}$ Dosen Universitas Pamulang, email : dosen01550@unpam.ac.id.

\section{ARTICLES INFORMATION}

ABSTRACT

\section{JURNAL SEKURITAS \\ (Saham, Ekonomi, Keuangan dan Investasi ) \\ Vol.3, No. 3, Mei 2020 \\ Halaman : $230-236$ \\ (C) LPPM \& Prodi Manajemen UNVERSITAS PAMULANG \\ ISSN (online) : 2581-2777 ISSN (print) : : 2581-2696}

\section{Keyword : \\ Harga saham; Virus corona; Volume Transaksi}

JEL. classification : C33, G21, G24, N15, N25

\section{Contact Author : \\ PRODI MANAJEMEN UNPAM \\ JL.Surya Kencana No.1 Pamulang Tangerang Selatan - Banten \\ Telp. (021) 7412566, Fax (021) 7412491 Email : sekuritas@unpam.ac.id}

Kasus covid-19 pertama kali di Indonesia diumumkan pada 2 Maret 2020. Penelitian ini bertujuan untuk mengetahui apakah terjadi perbedaan yang signifikan dari harga saham dan volume transaksi saham karena adanya pandemi covid-19 (studi kasus pada PT. Ramayana Lestari Sentosa, Tbk). Data penelitian ini diambil 31 hari sebelum dan 31 hari setelah diumumkannya kasus pertama covid-19 di Indonesia. Data diolah dengan paired sample t-tes, dengan menggunakan SPSS versi 20. Dari hasil pengolah data, menunjukkan terjadi perbedaan signifikan pada harga saham sebelum dan sesudah diumumkannya kasus pertama covid-19 di Indonesia. Hal ini ditunjukkan dengan nilai signifikasi $0,00<0,05$. Dimana harga saham mengalami penurunan dibandingkan sebelum adanya kasus covid-19. Sedangkan untuk volume transaksi saham juga menunjukkan perbedaan yang signifikan. Dimana nilai signifikasinnya $0,01<0,05$. Volume transaksi saham sesudah pengumuman menunjukkan nilai yang meningkat.

The first case of the covid-19 in Indonesia was announced on March $2^{\text {nd }}$ 2020. This research aims to find out the significant difference between stock prices and transaction volume at PT. Ramayana Lestari Sentosa, Tbk due to covid-19 pandemic. These data have been taken for 31 days before and 31 days after the first announcement of covid-19 corona virus in Indonesia. The data have been processed by paired sample $t$ test using SPSS version 20. The data processing results showed that there is a significant difference stock price of PT. Ramayana Lestari Sentosa, Tbk. between before and after the first announcement of the covid-19 case in Indonesia. This is indicated by the significance value of $0.00<0.05$, which the stock price has decreased compared to before the covid-19 case. As for the volume transaction also showed difference significant, which the significance value is $0.01<0.05$. The transaction volume after the announcement of shares shows an increasing value. 


\section{A. PENDAHULUAN}

Kasus covid-19 muncul pertama kali di Wuhan, Cina, pada akhir tahun 2019. Penyebaran pandemi virus ini begitu cepat dari manusia ke manusia, dari satu Negara ke Negara lain, sehingga menyebar ke seluruh dunia, termasuk Indonesia. Masuknya kasus wabah covid-19 ke Indonesia, diumumkan pada 2 Maret 2020. Upaya yang dilakukan pemerintah untuk mencegah penyebaran wabah covid-19 ini, antara lain dengan melakukan physical distancing, menggunakan masker, meliburkan sekolah, melakukan work from home, dan sebagainya.

Adanya penyebaran wabah covid-19 yang begitu cepat ini, tentu saja membawa dampak terhadap perekonomian Indonesia. Indonesia melakukan pembatasan keluar rumah, sehingga banyak sektor-sektor ekonomi tertentu yang terkena dampak negatif dari virus tersebut. Ada beberapa perusahaan yang melakukan Pemutusan Hubungan Kerja (PHK), misalnya yang dilakukan oleh Ramayana di daerah Depok. Terdapat 87 karyawan Ramayana di City Plaza Depok, terkena pemutusan hubungan kerja (PHK).

Menurut Camelia (2020), "Kepada Liputan6.com, Store Manager City Plaza Depok, M Nukmal Amdar mengatakan, perusahaan memutuskan tidak lagi beroperasi sejak 6 April 2020. Keputusan ini diambil lantaran omzet penjualan menurun hingga 80 persen. Akibatnya, perusahaan pun tak mampu lagi menanggung semua biaya operasional."

Kondisi suatu perusahaan selain dilihat dari omzet yang diterima, juga bisa dilihat dari harga saham perusahaan tersebut. Harga saham menunjukkan seberapa besar penawaran dan permintaan yang terjadi pada saham tersebut. Apabila permintaan akan saham tersebut naik, maka harga saham juga naik. Sedangkan jika permintaan terhadap saham tersebut turun, maka harga saham tersebut juga akan ikut turun. Selain harga saham, kondisi perusahaan juga bisa dilihat dari banyaknya transaksi saham yang dijualbelikan pada perusahaan tersebut. Banyaknya transaksi saham ini, menunjukkan minat investor baik untuk membeli maupun untuk menjual saham perusahaan tersebut. Nilai banyaknya transaksi saham ini bisa dilihat pada volume transaksi saham perusahaan tersebut.

Pada kesempatan ini akan dilakukan penelitian mengenai dampak pandemi covid-19 terhadap perusahaan PT. Ramayana Lestari Sentosa, Tbk. Dimana peneliti akan menggunakan data harga saham dan juga volume transaksi saham sebelum adanya pengumuman nasional kasus pertama virus corona di Indonesia dan juga sesudah pengumuman tersebut.

Pada penelitian ini rumusan masalah dapat dituliskan antara lain :

1. Apakah terdapat perbedaan signifikan harga saham PT. Ramayana Lestari Sentosa, Tbk. sebelum dan sesudah pengumuman nasional kasus pertama covid-19?

2. Apakah terdapat perbedaan signifikan volume transaksi PT. Ramayana Lestari Sentosa, Tbk. sebelum dan sesudah pengumuman nasional kasus pertama covid-19?

\section{B. KAJIAN LITERATUR}

\section{Saham}

Menurut Hidayat dalam Ifa Nurmasari (2018), "Saham adalah tanda penyertaan, andil atau pemilikan seseorang atau lembaga dalam suatu perusahaan (Hidayat, 2010:96)". Saham terdiri dari dua macam, yaitu saham preferen atau saham istimewa dan saham biasa. Kedua saham tersebut mempunyai perbedaan pada hak dan kewajiban yang dimiliki oleh investor atau pemegang saham. Ketika investor mempunyai saham, investor akan mendapatkan keuntungan, yaitu berupa return saham. Tingkat pengembalian/return saham merupakan besarnya laba/return yang akan investor peroleh. Tingkat pengembalian atau return saham ini ada dua macam yaitu deviden dan capital gain. Laba yang diperoleh investor, yang disebabkan oleh nilai beli saham lebih kecil dibandingkan nilai jual disebut 
sebagai capital gain. Sementara itu deviden diartikan sebagai keuntungan bersih yang diperoleh perusahaan, yang diberikan kepada para pemilik perusahaan.

Selain sisi positif yaitu mendapatkan keuntungan, investasi saham juga mempunyai risiko. Risiko dari investasi saham ini antara lain risiko likuidasi dan capital loss. Capital loss adalah kerugian yang diperoleh investor karena nilai penjualan saham lebih kecil dibandingkan dengan nilai pembelian. Capital loss ini merupakan kebalikan dari capital gain. Sedangkan risiko likuidasi, menurut Ifa Nurmasari (2017), "merupakan risiko yang terjadi karena saham perusahaan yang kita miliki dinyatakan bangkrut oleh Pengadilan, atau perusahaan tersebut dibubarkan". Pada saat perusahaan bangkrut, pemegang saham akan mendapatkan haknya pada urutan terakhir, yaitu setelah perusahaan melunasi seluruh kewajiban hutangnya. Apabila seluruh hutang perusahaan sudah dilunasi dan masih terdapat sisa aktiva, maka akan dibagikan kepada seluruh pemegang saham. Tetapi apabila aktiva yang dimiliki perusahaan telah habis, maka pemegang saham akan kehilangan uang yang telah diinvestasikannya.

\section{Volume Transaksi}

Volume transaksi saham merupakan jumlah saham yang dijualbelikan pada periode tertentu. Besarnya volume transaksi saham ini menunjukkan seberapa besar minat investor untuk melakukan transaksi baik membeli maupun menjual saham suatu perusahaan. Nilai volume transaksi yang tinggi, belum tentu menunjukkan harga saham yang tinggi. Nilai volume transaksi ini bisa berubah karena adanya peristiwa yang terjadi baik di dalam itu sendiri maupun peristiwa lain yang terjadi di luar perusahaan.

\section{Kerangka Berfikir}

\section{Pengumuman kasus pertama Covid-19 di Indonesia}

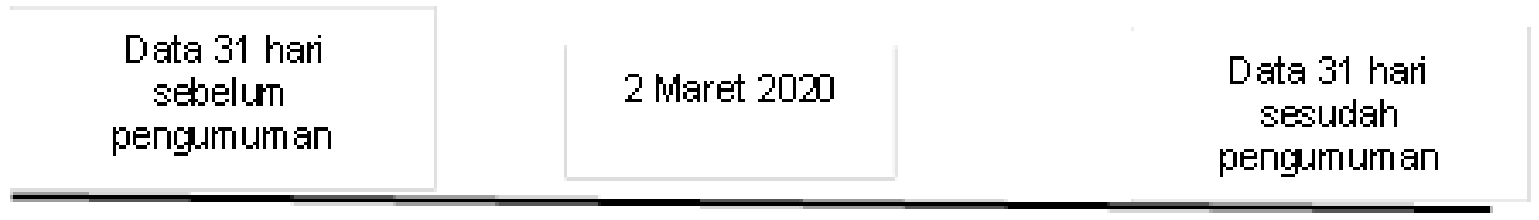

Perbedaan harga saham dan volume transaks

sebelum dan sesudah kasus pertama covid-19

\section{Hipotesis}

"Hipotesis adalah jawaban sementara terhadap rumusan masalah penelitian, dimana rumusan masalah penelitian telah dinyatakan dalam bentuk kalimat pertanyaan" (Sugiyono, 2016:64). Hipotesis merupakan jawaban sementara berdasarkan teori yang ada. Pada penelitian ini terdapat dua hipotesa. Yang pertama, diduga pada harga saham terdapat perbedaan signifikan sebelum diumumkannya kasus pertama covid-19 di Indonesia pada PT. Ramayana Lestari Sentosa, Tbk dengan sesudah pengumuman. Dan yang kedua adalah diduga terdapat perbedaan signifikan volume transaksi saham sebelum dan sesudah diumumkannya kasus pertama covid-19 di Indonesia pada PT. Ramayana Lestari Sentosa, Tbk. 


\section{METODOLOGI PENELITIAN}

Pada penelitian ini digunakan data sekunder, yaitu data harga saham dan volume transaksi dari PT. Ramayana Lestari Sentosa, Tbk yang diambil dari internet. Data yang diambil adalah 31 hari sebelum dan 31 hari setelah diumumkannya kasus pertama covid-19 yaitu pada 2 Maret 2020. Pada penelitian ini menggunakan data yang didapatkan dari website yahoo finance. Harga saham yang digunakan adalah pada saat penutupan atau biasa disebut closing price. Data closing price saham yang digunakan adalah data harian. Sementara itu untuk data volume transaksi diambil dari volume transaksi saham harian PT. Ramayana Lestari Sentosa, Tbk.

Pada penelitian ini menggunakan paired sample $t$-test. Pengujian ini digunakan untuk mengukur seberapa besar perbedaan harga saham dan volume transaksi saham PT. Ramayana Lestari Sentosa, Tbk, sebelum diumumkannya kasus covid-19 yang terjadi pertama kali di Indonesia dan sesudah pengumuman. Data pada penelitian ini diolah dengan menggunakan SPSS versi 20.

Pada penelitian ini, variabel-variabel yang digunakan adalah :

1. Data sebelum pengumuman nasional kasus covid-19 di Indonesia untuk petama kali $\left(X_{1}\right)$.

Data sebelum pegumuman nasional kasus covid-19 di Indonesia untuk pertama kali ini meliputi data harga saham dan volume transaksi pada PT. Ramayana Lestari Sentosa, Tbk. Pada penelitian ini, data yang diambil sebelum kasus pertama virus corona sebanyak 31.

2. Data setelah pengumuman nasional kasus covid-19 di Indonesia untuk pertama kali $\left(X_{2}\right)$

Data sesudah pengumuman nasional kasus covid-19 di Indonesia untuk pertama kali ini meliputi data harga saham dan volume transaksi pada PT. Ramayana Lestari Sentosa, Tbk. Pada penelitian ini, data yang diambil sesudah kasus pertama covid-19 sebanyak 31.

3. Pengumuman nasional pertama kasus covid-19 di Indonesia untuk pertama kali.

Kasus pertama covid-19 di Indonesia terhitung mulai 2 Maret 2020, yaitu pada saat pemerintah mengumumkan pertama kali terdapat orang Indonesia yang terkena covid- 19 .

\section{HASIL DAN PEMBAHASAN}

\section{Perbedaan harga saham PT. Ramayana Lestari Sentosa, Tbk. sebelum dan sesudah diumumkannya kasus pertama covid-19 di Indonesia.}

Hasil perhitungan statistik deskriptif dari harga saham sebelum pengumuman kasus covid-19 pertama di Indonesia dan setelahnya, dapat dibaca pada tabel 1. Harga saham sebelum diumumkannya kasus pertama covid-19 mempunyai nilai rata-rata sebesar Rp. 1.052,72 dan harga saham sesudah diumumkannya kasus pertama covid-19 mempunyai nilai rata-rata sebesar Rp. 628,48. Data yang diambil adalah 31 data sebelum dan 31 data sesudah diumumkannya kasus pertama covid-19. Apabila kita lihat dari nilai rata-rata pada tabel 1, terdapat penurunan harga saham setelah adanya pengumuman kasus covid-19 pertama di Indonesia.

Tabel 1

Statistik Deskriptif Harga Saham

Statistik Paired Samples

\begin{tabular}{|ll|l|l|l|l|}
\hline & & Rata-rata & $\mathrm{N}$ & Std. Deviasi & $\begin{array}{l}\text { Std. } \\
\text { Mean }\end{array}$ \\
\hline Pair 1 & $\mathrm{X}_{1}$ & 1052.74 & 31 & 80.092 & 14.385 \\
& $\mathrm{X}_{2}$ & 628.48 & 31 & 168.013 & 30.176 \\
\hline
\end{tabular}

Sumber : Data dioalah (2020) 
Tabel 2 menunjukkan hasil olah data dari uji paired sample $t$-Test harga saham yang dioperasikan dengan SPSS versi 20. Pada tabel 2 tersebut, terlihat bahwa nilai signifikasi 0,00 . Hasil signifikasi tersebut lebih kecil dari 0,05 . Nilai ini menunjukkan bahwa $\mathrm{H}_{\mathrm{a} 1}$ diterima dan $\mathrm{H}_{01}$ ditolak, yang artinya terdapat perbedaan signifikan antara harga saham pada PT. Ramayana Lestari Sentosa, Tbk. sebelum dan sesudah diumumkannya kasus pertama covid-19 di Indonesia. Pada tabel 2 juga menunjukkan perbedaan nilai rata-rata harga saham pada PT. Ramayana Lestari Sentosa, Tbk. sebelum dan sesudah diumumkannya kasus pertama covid-19 di Indonesia sebesar 424,258. Besarnya nilai ini positif, menunjukkan bahwa harga saham sebelum pengumuman mempunyai nilai rata-rata lebih besar dibandingkan dengan nilai rata-rata harga saham sesudah pengumuman. Hal ini menunjukkan adanya penurunan rata-rata harga saham pada PT. Ramayana Lestari Sentosa, Tbk. yang disebabkan oleh adanya kasus covid-19.

Tabel 2

Paired Sample t-Test Harga Saham

\section{Uji Paired Samples}

\begin{tabular}{|c|c|c|c|c|c|c|c|c|}
\hline & \multicolumn{5}{|c|}{ Paired Differences } & \multirow[t]{3}{*}{$\mathrm{T}$} & \multirow[t]{3}{*}{ df } & \multirow{3}{*}{$\begin{array}{l}\text { Sig. (2- } \\
\text { tailed) }\end{array}$} \\
\hline & \multirow[t]{2}{*}{ Mean } & \multirow[t]{2}{*}{$\begin{array}{l}\text { Standard } \\
\text { Deviasi }\end{array}$} & \multirow[t]{2}{*}{$\begin{array}{l}\text { Standard } \\
\text { Error } \\
\text { Mean }\end{array}$} & \multicolumn{2}{|c|}{$\begin{array}{l}95 \% \text { Confidence } \\
\text { Interval of the } \\
\text { Difference } \\
\end{array}$} & & & \\
\hline & & & & Lower & Upper & & & \\
\hline Pair $1 \quad X_{1}-X_{2}$ & 424.258 & 120.171 & 21.583 & 380.179 & 468.337 & 19.657 & 30 & .000 \\
\hline
\end{tabular}

Sumber : Data diolah (2020)

Pada PT. Ramayana Lestari Sentosa, Tbk. mengalami penurunan harga saham yang signifikan karena kasus covid-19 yang terjadi di Indonesia. Untuk mencegah penyebaran covid-19 ini, pemerintah meminta masyarakat untuk selalu tinggal di rumah. Tentu saja hal ini menyebabkan masyarakat mengurangi pembelian barang-barang pada Ramayana, dan menyebabkan penurunan omset pada Ramayana. Penurunan pendapatan ini, bahkan menyebabkan beberapa karyawan mengalami PHK. Bagi investor, tentu saja hal ini menjadi hal yang merugikan, karena investor berpeluang besar tidak mendapatkan dividend dan bisa mengalami capital loss.

\section{Perbedaan Volume Transaksi PT. Ramayana Lestari Sentosa, Tbk. sebelum dan sesudah diumumkannya kasus pertama covid-19 di Indonesia.}

Hasil perhitungan statistik deskriptif dari volume transaksi sebelum dan sesudah pengumuman kasus covid-19 pertama di Indonesia, ditunjukkan oleh tabel 3. Dari tabel tersebut, memperlihatkan bahwa nilai rata-rata volume transaksi sebelum diumumkannya kasus pertama covid-19 adalah 5.454.712,90 dan nilai rata-rata volume transaksi sesudah diumumkannya kasus pertama covid-19 adalah 16.060.709,68. Data yang diambil adalah 31 data sebelum dan 31 data sesudah diumumkannya kasus pertama covid-19 yang ada di Indonesia. Apabila kita lihat dari nilai rata-rata pada tabel 3, terdapat kenaikan volume transaksi saham yang dijual belikan setelah adanya pengumuman kasus covid-19 pertama di Indonesia. 
Tabel 3

Statistik Deskriptif dari Volume Transaksi

Statistik Paired Samples

\begin{tabular}{|rl|r|r|r|r|}
\hline & & \multicolumn{1}{|c|}{ Rata-rata } & N & \multicolumn{1}{c|}{ Std. Deviasi } & \multicolumn{1}{c|}{ Std. Error Mean } \\
\hline \multirow{2}{*}{ Pair 1 } & $\mathrm{X}_{1}$ & 5454712.90 & 31 & 3771616.768 & 677402.369 \\
& $\mathrm{X}_{2}$ & 16060709.68 & 31 & 15711460.100 & 2821861.537 \\
\hline
\end{tabular}

Sumber : Data diolah (2020)

Tabel 4

Uji Paired Sample t-Test Volume Transaksi

Uji Paired Samples

\begin{tabular}{|c|c|c|c|c|c|c|c|c|}
\hline & \multicolumn{5}{|c|}{ Paired Differences } & \multirow[t]{3}{*}{$\mathrm{t}$} & \multirow[t]{3}{*}{ Df } & \multirow[t]{3}{*}{ Sig. (2 tailed) } \\
\hline & \multirow[t]{2}{*}{ Mean } & \multirow[t]{2}{*}{$\begin{array}{c}\text { Standard } \\
\text { Deviasi }\end{array}$} & \multirow[t]{2}{*}{$\begin{array}{l}\text { Standard. } \\
\text { Error } \\
\text { Mean }\end{array}$} & \multicolumn{2}{|c|}{$\begin{array}{c}95 \% \text { Confidence } \\
\text { Interval of the } \\
\text { Difference }\end{array}$} & & & \\
\hline & & & & Lower & Upper & & & \\
\hline $\begin{array}{cr}\text { Pair } 1 & \mathrm{X}_{1} \\
& -\mathrm{X}_{2}\end{array}$ & $\begin{array}{r}1060599 \\
6.774\end{array}$ & $\begin{array}{r}16878955 \\
196\end{array}$ & $\begin{array}{r}3031549.8 \\
46\end{array}$ & $\begin{array}{r}167972 \\
47.524\end{array}$ & $\begin{array}{r}4414746 . \\
024\end{array}$ & -3.499 & 30 & .001 \\
\hline
\end{tabular}

Sumber : data diolah, 2020

Untuk melihat perbedaan volume transaksi sebelum dan sesudah diumumkannya kasus covid-19 pertama di Indonesia dilakukan dengan menggunakan uji paired sample t-Test. Uji ini diolah dengan menggunakan SPSS versi 20 , yang dapat dilihat pada tabel 4 . Pada tabel tersebut, terlihat bahwa nilai signifikasi 0,01 , nilai ini lebih kecil dari 0,05. Berdasarkan nilai signifikasi tersebut, maka $\mathrm{H}_{01}$ ditolak dan $\mathrm{H}_{\mathrm{a} 1}$ diterima. Dari hasil uji tersebut berarti teradapat perbedaan signifikan antara volume transaksi pada PT. Ramayana Lestari Sentosa, Tbk. sebelum dan sesudah diumumkannya kasus pertama covid-19 di Indonesia. Pada tabel 4 juga menunjukkan perbedaan nilai rata-rata volume transaksi pada PT. Ramayana Lestari Sentosa, Tbk. sebelum dan sesudah diumumkannya kasus pertama covid-19 di Indonesia sebesar -10.605.996,774. Besarnya nilai ini negatif, yang artinya sebelum pengumuman kasus pertama covid-19 di Indonesia mempunyai nilai rata-rata lebih kecil dibandingkan nilai rata-rata volume transaksi sesudah pengumuman. Nilai ini menunjukkan adanya peningkatan rata-rata volume transaksi saham pada perusahaan Ramayana yang disebabkan oleh adanya kasus covid-19.

Pada PT. Ramayana ini, mengalami peningkatan volume transaksi saham yang signifikan karena adanya kasus yang diakibatkan oleh covid-19. Peningkatan volume transaksi saham ini terjadi karena meningkatnya aktivitas jual beli saham pada PT. Ramayana Lestari Sentosa, Tbk. Peningkatan volume transaksi saham ini, tidak diikuti dengan peningkatan harga saham. Peristiwa tersebut menunjukkan bahwa banyak investor yang menjual sahamnya, karena kekhawatiran investor akan mengalami kerugian yang diakibatkan oleh dampak pandemi wabah covid-19.

\section{E. KESIMPULAN}

Kesimpulan yang didapatkan dari penelitian ini yaitu dengan uji paired sample t-test, dari harga saham PT. Ramayana Lestari Sentosa, Tbk. sebelum dan sesudah diumumkannya kasus pertama covid-19 di Indonesia memperlihatkan perbedaan yang signifikan. Hal ini ditunjukkan dengan nilai signifikasi $0,00<0,05$. Demikian juga untuk volume transaksi 
saham PT. Ramayana Lestari Sentosa, Tbk. terdapat perbedaan yang signifikan dari sebelum diumumkannya kasus pertama covid-19 di Indonesia dengan sesudah pengumuman. Hal ini ditunjukkan dengan nilai signifikasi 0,01<0,05.

Dengan adanya kasus covid-19 ini menyebabkan harga saham mengalami penurunan, sementara volume transaksi mengalami peningkatan. Oleh karena itu, bagi perusahaan sebaiknya merubah strategi penjualan, dengan lebih gencar melakukan penjualan secara online, agar omset yang didapatkan bisa meningkat. Peningkatan pendapatan akan dapat menarik minat investor untuk membeli saham perusahaan tersebut. Sehingga harga saham bisa naik kembali.

\section{DAFTAR PUSTAKA}

Camelia (2020, April 9). Tangis Pilu Puluhan Karyawan Ramayana Depok Terkena PHK Akibat Corona. Dibaca April, 18, 2020, dari https://www.liputan6.com/citizen6/read/4222812/tangis-pilu-puluhan-karyawanramayana-depok-terkena-phk-akibat-corona.

Fitria, T. A., Afifudin, A., \& Junaidi, J. (2019). "Analisis Dampak Reverse Stock Split Terhadap Harga Saham Dan Volume Perdagangan Saham (Studi Kasus Perusahaan Manufaktur di Bursa Efek Indonesia Periode 2010-2018)". Jurnal IImiah Riset Akuntansi, 8(01).

Hartono, J. 2018. "Studi Peristiwa Menguji Reaksi Pasar Modal Akibat Suatu Peristiwa". BPFE- Yogyakarta.

Hezee, E. Analisis Teknikal : Volume Naik, Harga Turun. Diakses pada Mei, 5, 2020, dari http://www.sahamgain.com/2019/08/analisis-teknikal-volume-naik-harga.html.

Kadim, A., \& Sunardi, N. (2018). Pengaruh analisa kesahatan dan kebangkrutan dengan pendekatan altman z-score terhadap harga saham Industri Konstruksi di indonesia yang listing di BEI periode 2013-2017. Jurnal SEKURITAS (Saham, Ekonomi, Keuangan dan Investasi), 1(4).

Nurmasari, I. (2017). "Analisis Current Ratio, Return On Equity, Debt to Equity Ratio dan Pertumbuhan Pendapatan Berpengaruh Terhadap Return Saham Pada Perusahaan Pertambangan Di Bursa Efek Indonesia 2010-2014". Jurnal Kreatif, 5(1), 112-131.

Nurmasari, I. (2018). "Pengaruh Rasio Keuangan dan Pertumbuhan Pendapatan Terhadap Return Saham Pada Perusahaan Perkebunan Di Bursa Efek Indonesia 2010-2017". Jurnal SEKURITAS (Saham, Ekonomi, Keuangan dan Investasi), 2(1).

Sugiyono. 2016. "Metode Penelitian Kombinasi. Penerbit Alfabeta". Bandung.

Sunardi, N. (2018). Kinerja Perusahan Pendekatan Du Pont System Terhadap Harga Dan Return Saham (Perusahaan yang tergabung dalam Industri Real Estate dan Properti yang terdaftar di Bursa Efek Indonesia Tahun 2011-2017). JIMF (Jurnal IImiah Manajemen Forkamma), 1(3).

Sunardi, N. (2019). Profitabilitas, Likuiditas, Dan Multiplier Equity Pengaruhnya Terhadap Harga Serta Return Saham Pada Industri Manufaktur Tahun 20122017. INOVASI, 6(1), 58-73.

Sunardi, N., \& Ula, L. N. R. (2017). Pengaruh BI Rate, Inflasi Dan Kurs Terhadap Indeks Harga Saham Gabungan (IHSG). Jurnal Sekuritas: Saham, Ekonomi, Keuangan dan Investasi, 1(2), 27-41.

Yahoo Finance. Diakses pada April, 18, 2020, dari https://finance.yahoo.com/quote/RALS/history?p=RALS 